\title{
ANALISIS PENERAPAN PENGELOLAAN KEUANGAN BADAN LAYANAN UMUM (PK-BLU) POLITEKNIK KESEHATAN KEMENKES BENGKULU
}

\author{
Agung Riyadi, Hermansyah
Politeknik Kesehatan Kementerian Kesehatan Bengkulu, Jurusan Keperawatan, Jalan Indragiri Nomor 03 Padang Harapan Kota Bengkulu zakyagung@yahoo.co.id

\begin{abstract}
BLU, there is still the manager of the department / study program who do not understand the flexibility of financial management that offers efficiency and productivity, have not seen the role of the supervisory board (a god) to the financial coaching BLU. Value turnover was still below the minimum requirement, Operational Cooperation is still very minimal, opinions BLU is still small (under 15 billion) and the remuneration of the BLU can not be granted to managers and employees BLU officials. The purpose of this study was to determine the application overview Managed Health Polytechnic BLU MoH Bengkulu. This research was conducted with qualitative. The unit of analysis of research data is Poltekkes MoH Bengkulu. The subject of research is the Director, Pudir, Kasubbag Adum, Kaur Finance, kaur and Staff Officer, Treasurer BLU, Treasurer non-tax revenues, financial reporting staff, Ka. Planning Unit, Kajur/Sekjur, department managers, lecturers and students of each department / study program. The sampling technique purposive sampling, namely the determination of the sample based on certain criteria and based on the consideration of researchers. The results showed that 1) The perception of the BLU is different - different. 2) Budget planning is already using the RBA as the budget plan. 3) Source BLU reception from the state budget in the form of pure Rupiah and non-tax revenues came from students and other funding sources. 4) Has had three accounts that have been approved by the Ministry of finance. 5) The financial statements BLU consist of the balance sheet, budget realization reports, activity reports, cash flow statement and notes to the financial statements and there are no clear technical guidelines on financial reporting BLU. 6) Have been prepared BLU performance accountability report. 7) Never before have a budget deficit, and is still running a budget surplus. 8) Dewas still held by officials not yet fully substitute god that can run all functions of a god .. 9) Monitoring of financial management BLU implemented by SPI, Itjend, and the Office of Public Accountants. 10) The remuneration system BLU yet fully implemented, the implementation of remun still follow the pattern of the ministries / agencies.
\end{abstract}

Keywords: Management, Finance, Agency, Service, Public

Abstrak : Setelah dua tahun menerapkan pengelolaan keuangan BLU, masih ada pengelola jurusan/prodi yang belum memahami fleksibilitas pengelolaan keuangan yang menonjolkan efisiensi dan produktivitas, belum terlihat peran dewan pengawas (dewas) terhadap pembinaan keuangan BLU. Nilai omzet yang masih di bawah syarat minimal, Kerjasama Operasional masih sangat minim, pendapat BLU masih kecil (dibawah 15 Milyar) dan remunerasi dari BLU belum dapat diberikan kepada Pejabat pengelola dan pegawai BLU. Tujuan penelitian ini adalah mengetahui gambaran penerapan Pengelolaan BLU Politeknik Kesehatan Kemenkes Bengkulu. Penelitian ini dilakukan dengan kualitatif. Unit analisis data penelitian adalah Poltekkes Kemenkes Bengkulu. Subjek penelitian adalah Direktur, Pudir, Kasubbag Adum, Kaur Keuangan, kaur dan staf Kepegawaian, Bendahara BLU, Bendahara PNBP, staf pelaporan keuangan, Ka. Unit Perencanaan, Kajur/Sekjur, pengelola jurusan, dosen dan mahasiswa setiap jurusan/prodi. Teknik pengambilan sampel dengan purposive sampling, yakni penetapan sampel berdasarkan kriteria tertentu dan berdasarkan pertimbangan peneliti. Hasil penelitian menunjukan bahwa 1) Persepsi tentang BLU masih berbeda - beda. 2) Perencanaan anggaran sudah menggunakan RBA sebagai rencana anggaran. 3) Sumber penerimaan BLU berasal dari APBN berupa Rupiah murni dan 


\begin{abstract}
PNBP yang berasal dari mahasiswa dan sumber dana lainnya. 4) Telah memiliki tiga rekening yang telah disetujui oleh Kementrian keuangan. 5) Laporan keuangan BLU terdiri dari laporan neraca, laporan realisasi anggaran, laporan aktivitas, laporan arus kas dan catatan atas laporan keuangan serta belum ada petunjuk tehnis yang jelas tentang pelaporan keuangan BLU. 6) Telah disusun laporan akuntabilitas kinerja BLU. 7) Belum pernah mengalami defisit anggaran dan sampai saat ini masih mengalami surplus anggaran. 8) Dewas masih dilaksanakan oleh pejabat pengganti dewas yang belum sepenuhnya dapat menjalan seluruh fungsi dewas.. 9) Pengawasan pengelolaan keuangan BLU dilaksanakan oleh SPI, Itjend, dan Kantor akuntan Publik. 10) Sistem remunerasi BLU belum dilaksanakan dengan sepenuhnya, pelaksanaan remun masih mengikuti pola kementrian/lembaga.
\end{abstract}

Kata Kunci : Pengelolaan, Keuangan, Badan, Layanan, Umum

Instansi pemerintah yang tugas pokok dan fungsinya memberikan pelayanan kepada masyarakat dapat menerapkan pola pengelolaan keuangan BLU (badan layanan umum) yang fleksibel, berupa keleluasaan untuk menerapkan praktek-praktek bisnis yang sehat dalam rangka memaksimalkan pelayanan kepada masyarakat dengan tetap menonjolkan produktivitas, efisiensi, dan efektifitas.

BLU pada dasarnya adalah alat untuk meningkatkan kinerja pelayanan publik melalui penerapan manajemen keuangan yang berbasis pada hasil, profesionalitas, akuntabilitas dan transparansi (Waluyo, 2011). Instansi yang menggunakan model BLU harus menerapkan sistem anggaran berbasis kinerja dan akuntansi berbasis akrual (Amirya $\mathrm{dkk}, 2011$ )

Berdasarkan Keputusan Menteri Keuangan Nomor 19/KMK.05/2012, Politeknik Kesehatan Kemenkes Bengkulu menerapkan Pengelolaan Keuangan Badan Layanan Umum. Setelah dua tahun menerapkan pengelolaan keuangan BLU, masih ada pengelola jurusan/prodi yang belum memahami fleksibilitas pengelolaan keuangan yang menonjolkan efisiensi dan produktivitas, masih banyak pengelola yang belum memahami penerapan tarif layanan, disamping itu, belum terlihat peran dewan pengawas (dewas) terhadap pembinaan keuangan BLU. Nilai omzet tahunan yang masih di bawah syarat minimal, Kerjasama Operasional masih sangat minim, pendapat BLU masih kecil (dibawah 15 Milyar) dan remunerasi dari BLU belum dapat diberikan kepada Pejabat pengelola dan pegawai BLU.
Sehubungan dengan hal tersebut maka penelitian ini bertujuan mengetahui penerapan Pengelolaan Keuangan Badan Layanan Umum Politeknik Kesehatan Kemenkes Bengkulu.

\section{BAHAN DAN CARA KERJA}

Jenis Penelitian ini adalah Kualitatif. Populasi dalam penelitian ini adalah Seluruh civitas akademika di lingkungan Poltekkes Ke-menkes Bengkulu. Sampel dari penelitian ini ditentukan secara purposive, dengan mempertimbangkan peran dan kedudukan seseorang didalam sistem dan pengelolaan Badan layanan umum Poltekkes Kemenkes Bengkulu, yaitu : Direktur, Pudir, Kasubbag Adum, Kaur Keuangan, kaur dan staf Kepegawaian/Penanggung jawab Remunerasi, Bendahara BLU, Bendahara PNBP, staf pelaporan keuangan, Ka. Unit Perencanan, Kajur/Sekjur, pengelola jurusan, dosen dan mahasiswa setiap jurusan/prodi. Penelitian menggunakan Data primer yang diperoleh dari penelitian di lapangan (Field research) yang secara teknis dilakukan dengan observasi serta wawancara terstuktur dengan responden. Penelitian dilaksanakan pada bu-lan Juni s.d. Nopember tahun 2014.

\section{HASIL}

\section{Persepsi tentang Badan Layanan Umum dan penerapan sistem tarif layanan}

Berdasarkan hasil wawancara dengan pengelola keuangan direktorat mengatakan bahwa :

"BLU adalah pengelolaan keuangan mandiri dan fleksibel yang diterapkan pada satuan kerja pemerintah yang dibentuk 
untuk memberikan pelayanan kepada masyarakat berupa penyediaan barang atau jasa yang dijual tanpa mengutamakan keuntungan dengan prinsip efisiensi dan produktifitas".

Hasil wawancara dengan dosen menyatakan bahwa:

"BLU adalah system pengelolaan keuangan dimana satker diberi keleluasaan, kemandirian dan fleksibilitas sesuai aturan yang berlaku, jadi poltekkes BLU dapat mengelola keuangannya dengan lebih bebas kalau dibandingkan dengan poltekkes non BLU."

Hasil wawancara dengan mahasiswa, dijelaskan bahwa BLU adalah system pengelolaan keuangan yang dilaksanakan di Poltekkes Kemenkes Bengkulu. Mahasiswa menyatakan :

"Belum merasakan manfaat langsung dari penerapan $P K B L U$, karena merasa tidak ada bantuan untuk organisasi HIMA/BEM, dan ada peningkatan biaya kuliah. Untuk pembayaran SPP lebih sederhana dengan system online melalui bank sehingga registrasi bisa lebih cepat".

\section{Perencanaan dan penganggaran}

Hasil wawancara dengan pengelola tingkat direktorat, yaitu ka. Unit perencanaan dan kaur. Keuangan tentang perencanaan dan penganggaran yang dilaksanakan adalah

"Perencanaan sudah dimulai dengan menyusun Renstra (Rencana strategis) yang kemudian menjadi dasar penyusunan Rencana bisnis anggaran (RBA). RBA disusun berdasarkan usulan tiap jurusan / prodi atau unit. Setelah penyusunan RBA kemudian di susun RKA-KL yang kemudian dibahas di tingkat pusat yaitu di BPPSDMKes, Irjend dan kementrian keuangan. Dalam pembahasan RKA-KL sering terjadi perubahan sehingga tidak sesuai dengan RBA yang telah disusun”.

Hal yang sama juga dikemukakan oleh pengelola jurusan/prodi, berdasarkan hasil wawancara diketahui bahwa:

"Penyusunan rencana anggaran dimulai dari menyusun dan mengusulkan RKA-KL ke tingkat direktorat. RBA disusun setelah mendapat petunjuk atau contoh dari direktorat. RBA belum sepenuhnya digunakan sebagai pedoman dan perencanaan anggaran".
Hal berbeda dikemukakan oleh mahasiswa, mahasiswa menga-takan :

"Kami tidak tahu bagaimana proses perencanaan anggaran, karena kami tidak pernah terlibat dan diiberi tahu tentang usulan rencana keuangan yang telah dilaksanakan....

\section{Pendapatan dan belanja}

Berdasarkan hasil wawancara dengan pengelola di tingkat direktorat yaitu ka.sub. bag adum dan pengelola keuangan diketahui bahwa :

"Sumber penerimaan BLU Poltekkes Kemenkes Bengkulu berasal dari APBN berupa Rupiah murni dan PNBP yang berasal dari mahasiswa dan sumber dana lainnya seperti usaha bisnis, bunga deposito dan hibah yang tidak mengikat. Pendapatan BLU sebagian besar berasal dari mahasiswa dalam bentuk DPP dan SPP. Pendapatan dari unit bisnis masih sangat sedikit bila disbandingkan dengan pendapat yang berasal dari mahasiswa."

"Sedangkan belanja BLU terdiri dari belanja barang, belanja jasa, belanja perjalanan dan belanja modal". Pada tahun 2014 poltekkes Kemenkes Bengkulu telah melaksanakan revisi anggaran enam kali untuk mengakomodir perubahan dan kebutuhan masing masing jurusan / prodi. Fleksibilitas sudah dilaksanakan dengan menambah belanja modal dari BLU sesuai dengan ambang batas kurang dari $10 \%$ \%".

\section{Pengelolaan kas}

Berdasarkan hasil wawancara dengan pengelola keuangan direktorat, dijelaskan bahwa

"Poltekkes Kemenkes Bengkulu telah memiliki tiga rekening yang telah disetujui oleh Kementrian keuangan yaitu rekening kelolaan, rekening opeasional dan rekening kelolaan kas".

Hasil wawancara dengan pengelola keuangan jurusan, di jelaskan bahwa

“..di jurusan tidak ada rekening, setiap mau belanja cukup mengajukan permintaan ke direktorat. Kesulitannya apabila ada kegiatan yang membutuhkan uang cepat maka tidak dapat dilaksanakan karena di tingkat direktorat tidak tersedia uang persediaan dan harus mengajukan dahulu permintaan dana yg waktunya sudah ditentukan yaitu 
setiap awal bulan. Untuk prodi yang jauh (di luar kota Bengkulu) terdapat kesulitan dalam pengiriman keuangan karena tidak terdapat rekening di prodi. Pengiriman uang untuk prodi jauh dilakukan melalui pengiriman cek dan uangnya dapat diambil di bank di daerah prodi tersebut untuk mengurangi risiko kehilangan uang di jalan. Pengelolaan keuangan di jurusan lebih mudah dan penyerapan sesuai dengan kebutuhan prodi/jurusan. Manfaat yang dirasakan oleh jurusan dengan system BLU adalah jika ada ketidak sesuaian bisa dilakukan revisi dengan cepat”.

Wawancara dengan bendahara penerimaan

"telah ada penerimaan dari bunga deposito, tidak ada hutang dan hanya terdapat penerimaan uang dimuka terhadap mahasiswa karena mahasiswa membayar di awal semester".

Bendahara juga mengatakan

"Penerimaan dari unit bisnis masih sangat kecil dan berasal dari sewa barang barang milik Negara terutama sewa auditorium".

\section{Akuntansi, pelaporan, dan pertanggung- jawaban keuangan}

Hasil wawancara dengan pengelola keuangan, pada bulan September 2014, dijelaskan bahwa Poltekkes Kemenkes Bengkulu telah melaksanakan laporan keuangan BLU dan laporan keuangan rupiah murni. Petugas pelaporan BLU menyatakan bahwa: "belum ada petunjuk tehnis yang jelas tentang pelaporan keuangan. Laporan keuangan BLU terdiri dari laporan neraca, leporan realisasi anggaran, laporan aktivitas, laporan arus kas dan catatan atas laporan keuangan".

Hasil wawancara dengan bendahara dijelaskan bahwa :

"Transaksi keuangan dilakukan setelah ada ajuan atas kebutuhan dana suatu unit/jurusan. Hasil dari kegiatan tersebut dilaporkan dan diubah dalam bentuk SPJ yang akan dimasukan ke aplikasi untuk diubah ke dalam laporan akuntasi. Laporan akuntasi ini yang akan dilaporkan setiap bulan secara internal dan eksternal per tiga bulan".

Hasil wawancara dengan dosen tentang pengelolaan keuangan BLU, di katakan bahwa:
" saya belum mendapatkan sosialisasi tentang pengelolaan keuangan BLU jadi belum begitu jelas tentang pengelolaan keuangan tersebut, tetapi saya merasa ada manfaat bagi institusi karena bisa mengelola sendiri keuangan yang ada ".

\section{Akuntabilitas kinerja}

Hasil wawancara dengan Kasubag. Adum mengatakan :

"setiap tahun mulai tahun 2013 telah dilaksanakan penilaian kinerja BLU baik oleh inspektur jendral Kementrian Kesehatan RI yang dilaksanakan di luar propinsi Bengkulu dan biasanya kita diundang untuk dilakukan penilaian. Selain itu juga ada penilaian oleh tim PK BLU kementrian keuangan dengan mengisi format penilaian yang sudah ditetapkan......

Mahasiswa mengatakan :

" kami tidak tahu bahwa telah dilakukan penilaian kinerja setiap tahun, dan menurut kami belum terasa betul adanya peningkatan pelayanan terhadap mahasiswa terutama dalam pembelajaran......

\section{Surplus dan defisit}

Hasil wawancara dengan bendahara BLU, didapatkan bahwa:

"Poltekkes Kemenkes Bengkulu belum pernah mengalam defisit anggaran. Selama ini uang yang ada di rekening operasional masih mencukupi untuk belanja operasional. Dalam tahun 2014, sampai dengan bulan nopember 2014 Poltekkes kemenkes Bengkulu bahkan surplus sekitar dua setengah milyar. Uang ini akan menjadi saldo untuk tahun 2015.

Pengelola keuangan jurusan mengatakan bahwa :

"setiap tahun kemungkinan terjadi surplus keuangan karena belanja yang dilaksanakan di tingkat jurusan tidak pernah habis sesuai rencana dan diakhir tahun masih terdapat sisa. Kami tidak tahu berapa jumlah surplusnya".

Begitu juga dengan mahasiswa, menyatakan :

" kami tidak pernah tahu apakah telah terjadi surplus atau deficit anggaran pada poltekkes. Kami berharap biaya kuliah kami bisa lebih murah dan kalau mungkin ada bantuan untuk uang kuliah kami terutama bagi mahasiswa yang berprestasi”. 


\section{Struktur organisasi}

Berdasarkan hasil wawancara dengan bagian adum, diketahui bahwa di Poltekkes Bengkulu telah ditambah dalam strukturnya yaitu SPI dan unit bisnis serta dewas. Untuk dewas karena pendapatan masih dibawah lima belas milyar maka masih dijabat oleh pejabat pengganti dewas yang dalam hal ini adalah Kepala BPPSDMKes. Sampai sejauh ini dewas di Poltekkes Kemenkes Bengkulu baru berperan dalam menetapkan RBA. Dari hasil wawancara dengan pengelola jurusan di jelaskan bahwa :

..."di jurusan terdapat pengelola jurusan yang meliputi ketua jurusan, sekretaris jurusan, ka. Prodi dll. Untuk BLU, jurusan belum merasa sebagai pejabat tehnis BLU karena merasa belum menerima surat Keputusannya".

\section{Pembinaan dan Pengawasan}

Berdasarkan hasil wawancara dengan bagian keuangan, dijelaskan bahwa pembinaan dan pengawasan pengelolaan keuangan BLU di lakukan oleh Kanwil Dirjen Perbendaharan (DJPB) Bengkulu. Pembinaan dilakukan minimal enam bulan sekali. Selain itu juga ada kerjasama dengan BPKP (Badan Pemeriksa Keuangan Propinsi) Bengkulu. Pernah dilakukan pendampingan pemeriksaan/Audit keuangan oleh BPKP Bengkulu berbarengan dengan audit SPI. Kaur keuangan menjelaskan bahwa di Poltekkes Kemenkes Bengkulu telah ada SPI (satuan pemeriksa internal) yang melakukan pemeriksaan/audit terhadap penggunaan keuangan di jurusan maupun di direktorat. Setiap tahun biasanya dilakukan pemeriksaan pengelolaan keuangan oleh Inspektur jendral Kementrian kesehatan. Selain itu juga dilakukan audit oleh Kantor akuntan $\mathrm{Pu}-$ blik ( KAP ) dengan hasil WTP untuk tahun 2013.

Hasil wawancara dengan kasub.bag adum mengatakan :

“.... belum terbentuk dewas secara resmi melalui SK, yang ada adalah pejabat pengganti dewas yang dilaksanakan oleh Kepala Badan BPPSDMKes. Dewas belum terbentuk karena pendapatan Poltekkes Kemenkes Bengkulu masih di bawah lima belas milyar per tahun dan belum dilaksanakannya remunerasi sehingga belum bisa membayar dewas seandainya dewas dibentuk ...."

\section{Remunerasi}

Berdasarkan hasil wawancara dengan pengelola direktorat, dijelaskan bahwa system remunerasi BLU belum berjalan sepenuhnya. Untuk remunerasi BLU berdasarkan pay for ferforman belum dilaksanakan. Poltekkes Kemenkes Bengkulu sedang dalam proses penyusunan remunerasi ber-dasarkan aturan BLU. Pada waktu wawan-cara, tenaga kependidikan menyatakan :

“....akan mendukung untuk remunerasi sesuai dengan system BLU karena menganggap penilaian kinerja akan lebih terukur dan jumlah uang yang diterima diyakini akan lebih besar bila dibandingkan dengan tukin".

\section{PEMBAHASAN}

\section{Persepsi tentang Badan Layanan Umum dan} penerapan sistem tarif layanan

Berdasarkan hasil penelitian diketahui bahwa persepsi tentang BLU masih berbedabeda, dimana terlihat bahwa pengelola lebih memahami tentang BLU dibandingkan dengan unsur dosen apalagi bila dibandingkan dengan mahasiswa. Mahasiswa diketahui tidak begitu memahami tentang BLU terlihat dari penjelasannya yang hanya menjelaskan BLU secara umum tanpa menjelaskan unsur-unsur flesibilitas, produktifitas atau prinsip bisnis yang sehat.

Hasil ini sesuai dengan penelitian Slamet (2014) yang menemukan bahwa terdapat persepsi yang berbeda dari stakeholder tentang keuntungan menjadi satker BLU yaitu 70,33\% menyatakan BLU untuk meningkatkan layanan pada mahasiswa dan 69,23\% menyatakan BLU lebih fleksibel.

Persamaan persepsi tentang BLU ini penting karena mempengaruhi peningkatan produktifitas dan kinerja BLU. Berdasarkan Undang-undang Nomor 23 Tahun 2005 tentang Pengelolaan Keuangan Badan Layanan Umum dinyatakan bahwa : "Badan Layanan Umum adalah instansi di lingkungan Pemerintah yang dibentuk untuk memberikan pe- 
layanan kepada masyarakat berupa penyediaan barang dan/atau jasa yang dijual tanpa mengutamakan mencari keuntungan dan dalam melakukan kegiatannya didasarkan pada prinsip efisiensi dan produktivitas".

Selanjutnya dalam ayat 2 dinyatakan, "Pola Pengelolaan Keuangan Badan Layanan Umum, yang selanjutnya disebut PPKBLU, adalah pola pengelolaan keuangan yang memberikan fleksibilitas berupa keleluasaan untuk menerapkan praktek-praktek bisnis yang sehat untuk meningkatkan pelayanan kepada masyarakat dalam rangka memajukan kesejahteraan umum dan mencerdaskan kehidupan bangsa.

\section{Perencanaan dan penganggaran}

Berdasarkan hasil penelitian diketahui bahwa dalam menyusun perencanaan anggaran pada Poltekkes Kemenkes Bengkulu belum sepenuhnya menggunakan RBA sebagai perencanaan anggaran tetapi masih menerapkan perencanaan menggunakan RKAKL dan mahasiswa tidak mengetahui bagaimana proses perencanaan anggaran dilaksanakan. RBA yang disusun masih merupakan formalitas saja dan cenderung mengikuti apa yang sudah disusun dalam RKAKL.

Hasil ini sejalan dengan penelitian Slamet (2014) yang menemukan bahwa Renstra belum menjadi panduan utama dalam melaksanakan tugas tugas satker BLU, dan kurangnya SDM yang professional dalam penyusunan renstra serta pimpinan kurang memahami dengan sempurna dokumen renstra.

Perencanaan dan penganggaran BLU pada prinsipnya tidak berbeda dengan perencanaan dan penganggaran pada kementerian/lembaga. RKA-K/L sebagai dokumen usulan anggaran (budget request) memuat sasaran terukur yang penyusunannya dilakukan secara berjenjang dari tingkat kantor/satuan kerja ke tingkat yang lebih tinggi (bottom-up) untuk melaksanakan penugasan dari menteri/pimpinan lembaga (top down). Dengan demikian dalam menyusun suatu Rencana Kerja dan Anggaran BLU harus menerapkan anggaran berbasis kinerja.
Setelah RKA-KL dan Undang-undang APBN disahkan, pimpinan BLU menyesuaikan usulan Rencana Bisnis dan Anggaran (RBA) menjadi RBA Definitif. RBA definitif digunakan sebagai acuan dalam menyusun DIPA BLU untuk diajukan dan mendapat pengesahan Menteri Keuangan c.q. Direktur Jenderal Perbendaharaan.

\section{Pendapatan dan belanja}

Hasil penelitian menunjukkan sumber penerimaan BLU Poltekkes Kemenkes Beng-kulu berasal dari APBN berupa Rupiah murni dan PNBP yang berasal dari mahasiswa dan sumber dana lainnya seperti usaha bisnis, bunga deposito dan hibah yang tidak mengikat, Sedangkan belanja BLU terdiri dari belanja barang, belanja jasa, belanja perjalanan dan belanja modal.

Hasil ini sesuai dengan Peraturan Pemerintah Nomor 23 Tahun 2005 tentang Pengelolaan Keuangan Badan Layanan Umum yang menyatakan bahwa Pendapatan BLU dapat berasal dari : Penerimaan anggaran yang bersumber dari APBN/APBD diberlakukan sebagai pendapatan BLU, Pendapatan yang diperoleh dari jasa layanan yang diberikan kepada masyarakat dan hibah tidak terikat yang diperoleh dari masyarakat atau badan lain merupakan pendapatan operasional BLU, Hibah terikat yang diperoleh dari masyarakat atau badan lain merupakan pendapatan yang harus diperlakukan sesuai dengan peruntukan dan Hasil kerjasama BLU dengan pihak lain dan/atau hasil usaha lainnya merupakan pendapatan bagi BLU.

Belanja BLU terdiri dari unsur biaya yang sesuai dengan struktur biaya yang dituangkan dalam RBA definitif. Pengelolaan belanja BLU diselenggarakan secara fleksibel berdasarkan kesetaraan antara volume kegiatan pelayanan dengan jumlah pengeluaran, mengikuti praktek bisnis yang sehat. Fleksibilitas pengelolaan belanja berlaku dalam ambang batas sesuai dengan yang ditetapkan dalam RBA. Belanja BLU yang melampaui ambang batas fleksibilitas harus mendapat persetujuan Menteri Keuangan/gubernur/bupati/walikota atas usulan 
menteri/pimpinan lembaga/kepala SKPD, sesuai dengan kewenangannya. Dalam hal terjadi kekurangan anggaran, BLU dapat mengajukan usulan tambahan anggaran dari APBN/APBD kepada Menteri Keuangan/PPKD melalui menteri/pimpinan lembaga/kepala SKPD sesuai dengan kewenangannya. Belanja BLU dilaporkan sebagai belanja barang dan jasa kementerian negara/lembaga/ SKPD/ pemerintah daerah.

\section{Pengelolaan kas}

Hasil Penelitian menunjukkan bahwa Poltekkes Kemenkes Bengkulu telah memiliki tiga rekening yang telah disetujui oleh Kementrian keuangan yaitu rekening kelolaan, rekening opeasional dan rekening kelolaan kas. Di jurusan tidak ada rekening, setiap mau belanja cukup mengajukan permintaan ke direktorat. Terdapat kesulitan dalam pengiriman keuangan pada Prodi yang jauh (di luar kota Bengkulu) karena tidak terdapat rekening di prodi. Pengiriman uang untuk prodi jauh dilakukan melalui pengiriman cek dan uangnya dapat diambil di bank di daerah prodi tersebut untuk mengurangi risiko kehilangan uang di jalan.

Hasil ini sesuai dengan pasal $16 \mathrm{UU}$ No. 23 tahun 2005 yang menyatakan bahwa pengelolaan kas BLU dilaksanakan berdasarkan praktek bisnis yang sehat. Pengelolaan kas BLU meliputi merencanakan penerimaan dan pengeluaran kas, melakukan pungutan pendapatan, mengelola rekening bank, melakukan pembayaran dan memanfaatkan kas yang menganggur (idle kas) jangka pendek untuk memperoleh pendapatan tambahan.

Pengelolaan kas BLU dapat dilakukan melalui: Penarikan dana yang bersumber dari APBN dengan menerbitkan SPM; Pembukaan Rekening Bank BLU oleh pimpinan BLU, sesuai dengan ketentuan yang berlaku kecuali dalam rangka cash management; dan Investasi jangka pendek dalam rangka cash management (jika terjadi surplus kas) pada instrumen keuangan dengan resiko rendah.

Dalam pengelolaan keuangan, BLU dapat memberikan piutang terkait dengan kegiatannya, yang dikelola secara tertib, efisien, ekonomis, transparan, dan bertanggung jawab serta dapat memberikan nilai tambah, sesuai dengan praktek bisnis yang sehat dan ketentuan perundang-undangan yang berlaku.

Piutang BLU dapat dihapus secara mutlak atau bersyarat oleh pejabat berwenang, yang nilainya ditetapkan secara berjenjang. Kewenangan penghapusan piutang secara berjenjang ditetapkan dengan Peraturan Menteri Keuangan dengan memperhatikan ketentuan peraturan perundang-undangan.

Dalam kegiatan operasional dengan pihak lain, BLU dapat memiliki utang yang dikelola secara tertib, efisien, ekonomis, transparan, dan bertanggung jawab, sesuai dengan praktek bisnis yang sehat. Pembayaran utang BLU pada prinsipnya menjadi tanggung jawab BLU. Pengelolaan utang harus sesuai dengan peruntukannya, utang jangka pendek ditujukan hanya untuk belanja operasional, sedangkan utang jangka panjang hanya untuk belanja modal. Hak tagih atas utang BLU kadaluarsa setelah lima tahun sejak utang tersebut jatuh tempo, kecuali ditetapkan lain oleh UU. Perikatan peminjaman/utang dilakukan sesuai dengan jenjang kewenangan yang diatur oleh Menteri Keuangan.

\section{Akuntansi, pelaporan, dan pertanggung- jawaban keuangan}

Hasil penelitian menunjukkan bahwa di Poltekkes Kemenkes Bengkulu belum ada petunjuk tehnis yang jelas tentang pelaporan keuangan. Berdasarkan Peraturan Pemerintah Nomor 23 Tahun 2005 dinyatakan bahwa BLU menyelenggarakan akuntansi sesuai dengan standar akuntansi keuangan yang diterbitkan oleh asosiasi profesi akuntan Indonesia, jika tidak ada standar akuntansi BLU yang bersangkutan dapat menerapkan standar akuntansi industri yang spesifik setelah mendapat persetujuan Menteri Keuangan. BLU mengembangkan dan menerapkan sistem akuntansi dengan mengacu pada standar akuntansi yang berlaku sesuai dengan jenis layanannya dan ditetapkan oleh menteri/pimpinan lembaga.

BLU menyampaikan laporan keuangan setiap triwulan kepada menteri/pimpinan 
lembaga berupa Laporan Realisasi Anggaran, Laporan Arus Kas, dan Catatan atas Laporan Keuangan dan Laporan keuangan yang lengkap (termasuk neraca dan ikhtisar laporan keuangan) pada setiap semester dan tahunan. Laporan-laporan tersebut disampaikan paling lambat satu bulan setelah periode pelaporan berakhir. Laporan keuangan unitunit usaha yang diselenggarakan dikonsolidasikan oleh BLU dan menjadi lampiran laporan keuangan BLU.

Penggunaan dan pertanggungjawaban keuangan BLU poltekkes kemenkes Bengkulu dilaksanakan setiap bulan dengan berpedoman pada Sistem operasional prosedur (SOP) yang telah ditetapkan oleh pimpinan BLU. Setiap awal bulan, jurusan/prodi atau unit mengajukan permintaan pembayaran atas kegiatan yang telah dilaksanakan. Permintaan uang ini kemudian di verifikasi oleh petugas verikator berdasarkan RBA/RKA-KL yang telah ditetapkan. Setelah diverifikasi, PPK (Pejabat pembuat komitmen) menerbitkan surat perintah bayar kepada masing-masing unit/jurusan. Bendahara BLU kemudian membayarkan uang sesuai permintaan dan setiap akhir bulan pertanggungjawaban dalam bentuk kwitansi dan lain-lain harus sudah kembali ke bendahara.

Hasil ini sesuai dengan Peraturan Pemerintah Nomor 76/PMK.05/2008 Setiap transaksi keuangan BLU harus diakuntansikan dan dokumen pendukungnya dikelola secara tertip. Sistem Akuntansi BLU meliputi sistem akuntansi keuangan, yang menghasilkan Laporan Keuangan pokok untuk keperluan akuntabilitas, manajemen, dan transparansi serta sistem akuntansi biaya, yang menghasilkan informasi biaya satuan (unit cost) per unit layanan, pertanggungjawaban kinerja ataupun informasi lain untuk kepentingan manajerial.

\section{Akuntabilitas kinerja}

Poltekkes Kemenkes Bengkulu telah menyusun laporan akuntabilitas kinerja. Laporan ini akan dinilai oleh inspektur Jendral Kementrian Kesehatan RI. Hasil ini sesuai dengan Peraturan Menteri Negara Pendaya- gunaan aparatur Negara dan reformasi birokrasi 25 tahun 2012. Yang menyatakan bahwa Pelaksanaan evaluasi akuntabilitas kinerja unit organisasi internal dilakukan oleh masing-masing Aparat Pengawasan Internal Pemerintah atau oleh suatu Tim Lintas Unit Kerja yang secara khusus diberi tugas oleh pimpinan Kementerian/Lembaga/ Pemerintah Daerah. Iktisar hasil evaluasi akuntabilitas kinerja unit organisasi internal, setiap tahun dilaporkan kepada Menteri Pendayagunaan Aparatur Negara dan Reformasi Birokrasi c.q. Deputi Bidang Pengawasan dan Akuntabilitas Aparatur, paling lambat akhir bulan September.

\section{Surplus dan defisit}

Hasil penelitian menunjukkan bahwa Poltekkes Kemenkes Bengkulu belum pernah mengalam defisit anggaran dan selalu surplus. Uang yang ada di rekening operasional masih mencukupi untuk belanja operasional. Surplus anggaran pada tahun sebelumnya belum dimanfaatkan dengan optimal seperti penggunaan anggaran surplus untuk tahun anggaran berikutnya atau untuk pengembangan institusi.

Kondisi ini sesuai dengan PP 23 tahun 2005, yang menyatakan bahwa Surplus anggaran BLU adalah selisih lebih antara pendapatan dengan belanja BLU yang dihitung berdasarkan laporan keuangan operasional berbasis akrual pada suatu periode anggaran. Estimasi surplus dalam tahun anggaran berjalan diperhitungkan dalam RBA tahun anggaran berikut untuk disetujui penggunaannya. Surplus anggaran BLU dapat digunakan dalam tahun anggaran berikutnya kecuali atas perintah Menteri Keuangan, disetorkan sebagian atau seluruhnya ke rekening kas umum negara dengan mempertimbangkan posisi likuiditas BLU.

\section{Struktur organisasi}

Hasil menunjukkan bahwa pada struktur organisasi Poltekkes Bengkulu telah ditambah dalam strukturnya yaitu SPI dan unit bisnis serta Dewan Pengawas. Untuk BLU, jurusan belum merasa sebagai pejabat thenis BLU karena merasa belum menerima surat Keputusannya. 
Berdasarkan kondisi ini ada beberapa hal yang belum sesuai yaitu BLU dikelola oleh Pejabat Pengelola BLU yang terdiri atas: Pemimpin BLU yang berfungsi sebagai penanggung jawab umum operasional dan keuangan BLU, Pejabat Keuangan BLU yang berfungsi sebagai penanggung jawab keuangan, Pejabat Teknis BLU dan Dewan Pengawas.

Pejabat tehnis, pengelola jurusan seharusnya merupakan pejabat tehnis BLU. Pejabat tehnis BLU yang berfungsi sebagai penanggung jawab teknis di bidang masingmasing. Pejabat tehnis BLU berkewajiban menyusun perencanaan kegiatan teknis di bidangnya, melaksanakan kegiatan teknis sesuai menurut RBA dan mempertanggungjawabkan kinerja operasional di bidangnya.

\section{Pembinaan dan pengawasan}

Hasil penelitian menujukkan bahwa pembinaan dan pengawasan pengelolaan keuangan BLU di Poltekkes Kemenkes Bengkulu di lakukan oleh Kanwil Dirjen Perbendaharan (DJPB) Bengkulu. Pembinaan dilakukan minimal enam bulan sekali. Selain itu juga ada kerjasama dengan BPKP (Badan Pemeriksa Keuangan Propinsi) Bengkulu. Pernah dilakukan pendampingan pemeriksaan/Audit keuangan oleh BPKP Bengkulu berbarengan dengan audit SPI. Di Poltekkes Kemenkes Bengkulu telah ada SPI (satuan pemeriksa internal), pemeriksaan pengelolaan keuangan oleh Inspektur jendral Kementrian kesehatan. Selain itu juga dilakukan audit oleh Kantor akuntan $\mathrm{Pu}-$ blik ( KAP ).

Hasil penelitian juga menunjukkan bahwa di Poltekkes Kemenkes Bengkulu belum terbentuk dewas secara resmi melalui SK, yang ada adalah pejabat pengganti dewas yang dilaksanakan oleh Kepala Badan BPPSDMKes. Dewas belum terbentuk karena pendapatan Poltekkes Kemenkes Bengkulu masih di bawah lima belas milyar per tahun dan belum dilaksanakannya remunerasi.

Hasil penelitian ini Sesuai dengan Peraturan Menteri Keuangan Nomor 109/ Pmk.05/2007, menyatakan bahwa dalam rangka pelaksanaan pengawasan terhadap pengelolaan BLU dapat dibentuk Dewan pengawas. Pembentukan Dewan Pengawas berlaku hanya pada BLU yang memiliki realisasi nilai omzet tahunan menurut laporan realisasi anggaran tahun terakhir, minimum sebesar Rp 15.000.000.000,00 (lima belas miliar rupiah), dan/atau nilai aset menurut neraca, minimum sebesar Rp 75.000.000.000,00 (tujuh puluh lima miliar rupiah).

Peraturan Pemerintah Nomor 23 Tahun 2005 menyatakan bahwa BLU diberikan fleksibilitas berupa keleluasaan penerapan praktek bisnis yang sehat untuk meningkatkan pelayanan kepada masyarakat, sebagai pengecualian pengelolaan keuangan negara pada umumnya. Diperlukan pembinaan dan pengawasan baik secara teknis dan keuangan, untuk memastikan tujuan pembentukan BLU berikut kewenangan pemberian layanan umum kepada masyarakat yang didelegasikan $\mathrm{K} / \mathrm{L}$ dapat berjalan baik dan sesuai ketentuan

Pejabat yang bertugas untuk mengawasi pengelolaan keuangan BLU adalah dewan pengawas. Dewan Pengawas melakukan pengawasan dan memberikan nasihat kepada pejabat pengelola BLU mengenai pengelolaan BLU, baik aspek layanan maupun aspek pengelolaan keuangan.

Dewan Pengawas mempunyai kewajiban untuk memberikan pendapat dan saran secara tertulis kepada menteri/pimpinan lembaga/Dewan Kawasan, Menteri Keuangan, dan pejabat pengelola mengenai RENSTRA dan RBA yang disusun oleh pejabat pengelola, melaporkan kepada menteri/pimpinan lembaga/Dewan Kawasan, Menteri Keuangan, apabila terjadi gejala penurunan kinerja BLU dan/atau penyimpangan atas ketentuan peraturan perundangundangan; dan menyampaikan laporan pelaksanaan tugas Dewas yang telah dilakukan kepada menteri/pimpinan lembaga/Dewan Kawasan, Menteri Keuangan.

\section{Remunerasi}

Hasil penelitian menunjukkan bahwa system remunerasi BLU di Poltekkes Ke- 
menkes Bengkulu belum berjalan sepenuhnya. Remunerasi yang diberikan baru sebatas pay for position yaitu gaji pokok berserta tunjangannya. Untuk remunerasi BLU berdasarkan pay for ferforman belum dilaksanakan. Saat ini pegawai terutama tenaga pendidik masih mendapat tunjangan kinerja yang telah ditetapkan oleh Kementrian Kesehatan, sedangkan untuk dosen mendapatkan tunjangan sertifikasi dosen.

Pejabat pengelola, dewan pengawas dan pegawai Badan Layanan Umum (BLU) dapat diberikan remunerasi berdasarkan tingkat tanggungjawab dan tuntutan profesionalisme yang diperlukan. Besaran gaji pemimpin BLU ditetapkan dengan mempertimbangkan Proporsionalitas.

Sesuai dengan Peraturan Menteri Kesehatan Republik Indonesia Nomor 68 Tahun 2014 Politeknik Kesehatan di Lingkungan Kementerian Kesehatan yang telah menerapkan pola pengelolaan keuangan Badan Layanan Umum harus menyesuaikan dengan Peraturan Menteri ini paling lambat 1 (satu) tahun sejak Peraturan Menteri ini diundangkan. Dalam peraturan ini juga dijelaskan bahawa Poltekkes BLU wajib menjamin sistem remunerasi yang layak dan adil, yang dapat memberikan manfaat kepada pegawai berupa rasa aman pada diri pegawai dalam kehidupan fisik maupun sosial secara wajar di lingkungan tempat pegawai ditugaskan bekerja, memberi penghargaan secara adil atas tingkat kompleksitas pekerjaan berdasarkan tugas pokok, peran dan fungsi pegawai dalam pekerjaannya, penghargaan atas pencapaian total target yang dibuktikan dengan data yang valid dan update, serta memberi penghargaan masa keberadaan atau masa kerja pegawai di Politeknik Kesehatan Kementerian Kesehatan.

Pegawai Politeknik Kesehatan Kementerian Kesehatan merupakan salah satu komponen yang menentukan keberhasilan Politeknik Kesehatan Kementerian Kesehatan dalam meningkatkan kinerja institusi dan menghadapi persaingan usaha yang semakin kompleks. Oleh karena itu sudah selayaknya pegawai diberikan remunerasi untuk mema- cu motivasi dalam menghadapi persaingan, membangun komitmen dalam bekerja dengan etos kerja tinggi dan berkesadaran mematuhi ketentuan-ketentuan pengelolaan keuangan Badan Layanan Umum dalam menghadapi persaingan global.

Penyusunan sistem remunerasi wajib memperhatikan kelayakan penerimaan bagi pegawai, yaitu didasarkan pada tingkat kewajaran kehidupan fisik dan sosial di lingkungan tempat pegawai ditugaskan dengan tetap menyesuaikan kondisi dan kemampuan keuangan Badan Layanan Umum Politeknik Kesehatan Kementerian Kesehatan yang bersangkutan.

\section{KESIMPULAN}

Hasil penelitian dapat disimpulkan bahwa : persepsi tentang BLU masih berbeda-beda, perencanaan anggaran sudah menggunakan RBA dan menerapkan perencanaan menggunakan RKA-KL, sumber penerimaan BLU berasal dari APBN berupa Rupiah murni dan PNBP yang berasal dari mahasiswa dan sumber dana lainnya. Poltekkes Kemenkes Bengkulu telah memiliki tiga rekening yang telah disetujui oleh Kementrian keuangan yaitu rekening kelolaan, rekening opeasional dan rekening kelolaan kas. Laporan keuangan BLU terdiri dari laporan neraca, laporan realisasi anggaran, laporan aktivitas, laporan arus kas dan catatan atas laporan keuangan serta belum ada petunjuk tehnis yang jelas tentang pelaporan keuangan BLU. Poltekkes Kemenkes Bengkulu telah menyusun laporan akuntabilitas kinerja BLU. Poltekkes Kemenkes Bengkulu belum pernah mengalam defisit anggaran dan sampai saat ini masih mengalami surplus anggaran. Pejabat pengganti dewas baru berperan dalam pengesahan RBA, unit/jurusan belum merasa sebagai pejabat tehnis BLU sehingga belum berperan secara optimal sesuai de-ngan tanggungjawabnya. Pengawasan pengelolaan keuangan BLU sudah dilaksanakan oleh SPI, Itjend, dan Kantor akuntan Publik. Sistem remunerasi BLU belum dilaksanakan dengan sepenuhnya, pelaksa-naaan remun masih mengikuti pola kemen-trian/lembaga. 
Disarankan kepada pihak Poltekkes Kemenkes Bengkulu adalah meningkatkan sosialisasi kepada dosen dan mahasiswa tentang pengelolaan BLU, pe-nyusunan rencana anggaran BLU sebaiknya cukup dengan RBA, perlu disusun buku pedoman

\section{DAFTAR RUJUKAN}

Amirya, M., Djamhuri, A., Ludigdo, U., 2011. Pengembangan Sistem Anggaran Dan Akuntansi Badan Layanan Umum Universitas Brawijaya: Sebuah Studi Interpretif. Malang : Universitas Brawijaya.

Effendi, 2003. Pengelolaan Perguruan Tinggi Menghadapi Tantangan Global. http://sofian.staff.ugm.ac.id/artikel/Effendi. diakses tanggal 14 Januari 2014.

Keputusan Menteri Keuangan Nomor 19/KMK.05/2012 tentang Penetapan Politeknik Kesehatan Kemenkes Bengkulu sebagai Instansi Pemerintah yang menerapkan Pengelolaan Keuangan Badan Layanan Umum.

Poltekkes Kemenkes Bengkulu, 2011. Rencana Startegis Bisnis 2011-2015. Bengkulu : Poltekkes Kemenkes.

Undang-Undang Nomor 17 Tahun 2003 tentang Keuangan Negara (Lembaran Negara Republik Indonesia Tahun 2003 Nomor 47, Tambahan Lembaran Negara Republik Indonesia Nomor 4286);

Undang-Undang Nomor 1 Tahun 2004 tentang Perbendaharaan Negara (Lembaran Negara Republik Indonesia Tahun 2004 Nomor 5, Tambahan Lembaran Negara Republik Indonesia Nomor 4355);

Peraturan Pemerintah Nomor 23 Tahun 2005 tentang Pengelolaan Keuangan Badan Layanan Umum (Lembaran Negara Republik Indonesia Tahun 2005 Nomor 48, Tambahan Lembaran Negara Republik Indonesia Nomor 4502).

Peraturan Menteri Keuangan Nomor 8/PMK.02/2006 tentang Kewenangan Pengadaan Barang/Jasa pada Badan Layanan Umum;

Peraturan Menteri Keuangan Nomor 9/PMK.02/2006 tentang Pembentukan Dewan Pengawas pada Badan Layanan Umum (dicabut dengan Peraturan Menteri Keuangan Nomor 109/PMK.05/2007);

Peraturan Menteri Keuangan Nomor 10/PMK.02/2006 tentang Pedoman Penetapan Remunerasi bagi Pejabat Pengelola, Dewan Pengawas, dan Pegawai Badan Layanan Umum sebagaimana telah diubah terakhir dalam pengelolaan keuangan dan pelaporan keuangan BLU, perlu pengem-bangan unit bisnis, perlu disusun sistem remunerasi sesuai dengan pengelolaan ke-uangan BLU, dan perlu dibentuk Dewan pengawas.

dengan Peraturan Menteri Keuangan Nomor 73/PMK.05/2007;

Peraturan Menteri Keuangan Nomor 66/PMK.02/2006 tentang Tata Cara Penyusunan, Pengajuan, Penetapan, dan Perubahan Rencana Bisnis dan Anggaran serta Dokumen Pelaksanaan Anggaran Badan Layanan Umum (dicabut dengan Peraturan Menteri Keuangan Nomor 44/PMK.05/2009);

Peraturan Menteri Keuangan Nomor 92/PMK.05/2011 tentang Rencana Bisnis dan Anggaran serta Pelaksanaan Anggaran Badan Layanan Umum;

Peraturan menteri keuangan nomor 76/pmk.05/2008 tentang pedoman akuntansi dan pelaporan keuangan badan layanan umum

Peraturan Menteri Keuangan Nomor 109/ Pmk.05 / 2007 Tentang Dewan Pengawas Badan Layanan Umum

Peraturan Dirjen Perbendaharaan Nomor PER30/PB/2011 tentang Mekanisme Pengesahan Pendapatan dan Belanja Satuan Kerja Badan Layanan Umum;

Peraturan Dirjen Perbendaharaan Nomor PER55/PB/2011 tentang Tata Cara Revisi Rencana Bisnis dan Anggaran Definitif dan Revisi Daftar Isian Pelaksanaan Anggaran Badan Layanan Umum

Peraturan Menteri Kesehatan Republik Indonesia Nomor 68 Tahun 2014 Tentang Pedoman Penyusunan Sistem Remunerasi Pegawai Politeknik Kesehatan Di Lingkungan Kementerian Kesehatan Yang Menerapkan Pola Pengelolaan Keuangan Badan Layanan Umum

Peraturan menteri negara pendayagunaan aparatur negara dan reformasi birokrasi nomor 25 tahun 2012 tentang Petunjuk Pelaksanaan Evaluasi Akuntabiitas Kinerja Instansi pemerintah.

Slamet, 2014. Implementasi Konsep Badan Layanan Umum pada Peerguruan Tinggi Agama Negeri dalam Rangka Mewujudkan Good University Governance.

Waluyo, 2011. Badan Layanan Umum Sebuah Pola Baru Dalam Pengelolaan Keuangan Di Satuan Kerja Pemerintah. Jurnal Pendidikan Akuntansi Indonesia, Vol. IX. No. 2 - Tahun 2011, Hlm. 1 - 15. 